NBER WORKING PAPER SERIES

THE ECONOMICS OF ENERGY SECURITY

\author{
Gilbert E. Metcalf \\ Working Paper 19729 \\ http://www.nber.org/papers/w19729 \\ NATIONAL BUREAU OF ECONOMIC RESEARCH \\ 1050 Massachusetts Avenue \\ Cambridge, MA 02138 \\ December 2013
}

Katherine Monson and Tyler Hoppenfeld served as excellent research assistants on this project. Metcalf gratefully acknowledges their assistance. When citing this paper, please use the following: Metcalf, GE. 2013. The Economics of Energy Security. Annual Review of Resource Economics: Submitted. Doi: 10.1146/annurev-resource-100913-012333 The views expressed herein are those of the author and do not necessarily reflect the views of the National Bureau of Economic Research.

NBER working papers are circulated for discussion and comment purposes. They have not been peerreviewed or been subject to the review by the NBER Board of Directors that accompanies official NBER publications.

(C) 2013 by Gilbert E. Metcalf. All rights reserved. Short sections of text, not to exceed two paragraphs, may be quoted without explicit permission provided that full credit, including $\odot$ notice, is given to the source. 
The Economics of Energy Security

Gilbert E. Metcalf

NBER Working Paper No. 19729

December 2013

JEL No. Q4

\begin{abstract}
$\underline{\text { ABSTRACT }}$
Energy security is the ability of households, businesses, and government to accommodate disruptions in supply in energy markets. This survey considers the economic dimensions of energy security, political and other non-economic security concerns and discusses policy approaches that could enhance U.S. energy security. A number of points emerge. First, energy security is enhanced by reducing consumption, not imports. A policy to eliminate oil imports, for example, will not enhance U.S. energy security whereas policies to reduce energy consumption can improve energy security. Second, energy security is distinct from considerations of energy externalities. Energy security taxes are appealing on political grounds but more difficult to justify on economic grounds. Finally, the contrasting concerns over energy security between policy makers and economists is striking. The survey notes some possible reasons for these differing views and suggests possible research opportunities in this area.
\end{abstract}

Gilbert E. Metcalf

Department of Economics

Tufts University

Medford, MA 02155

and NBER

gilbert.metcalf@tufts.edu 


\section{The Economics of Energy Security}

\section{Introduction}

Energy security has been a major policy agenda item for every U.S. president since Richard Nixon announced Project Independence in the early days of the 1973 OPEC oil embargo. ${ }^{1}$ While a central concern for policy makers, energy security has been of less interest to economists. The divergence in views and importance placed on this issue between economists and politicians is striking. This review considers the topic of energy security from an economic perspective. In section II, I review and critique the major economic concerns around energy markets that - loosely speaking - are lumped under the umbrella of energy security. The following section reviews various broader energy security considerations that go beyond standard economic considerations. In section IV I review various policy options that have been suggested to address energy security concerns. In a concluding section, I return to the issue of the differing perspectives between politicians and economists and ask whether the latter group is missing something fundamental in its analysis of energy security.

A common definition of energy security is the "availability of sufficient supplies at affordable prices" (Yergin, 2006). Such a definition is both intuitive and elusive. What do we mean by "sufficient supplies"? What is an "affordable" price? In 2013, many Europeans have managed to pay the equivalent of roughly $\$ 8$ per gallon for premium gasoline without suffering severe economic hardship; in contrast a price of under $\$ 4$ a gallon held in the United States in that time. ${ }^{2}$ While a price of $\$ 8$ per gallon might be manageable in the long run, the short run economic dislocations to the U.S. economy of a rapid price increase from the current price to a European price of $\$ 8$ would likely be significant. And at

\footnotetext{
1 In a radio address to the nation on Nov. 7, 1973, President Nixon said "Let us set as our national goal, in the spirit of Apollo, with the determination of the Manhattan Project, that by the end of this decade we will have developed the potential to meet our own energy needs without depending on any foreign energy sources. Let us pledge that by 1980, under Project Independence, we shall be able to meet America's energy needs from America's own energy resources. "Nixon (1973).

2 Energy prices are taken from International Energy Agency (2013).
} 
either price, low-income households may struggle to cover their energy costs; clearly the higher the price, the more difficult this becomes for an increasing share of households. But a definition based on the notion of affordability may be more useful for political rhetoric than for economic analysis.

The Congressional Budget Office (2012) defines energy security as "the ability of U.S. households and businesses to accommodate disruptions of supply in energy markets." This definition emphasizes the relation between energy access and household and business activity. Note that the definition does not address the ability of the U.S. government to accommodate energy supply disruptions. A major concern for policy makers is the availability of adequate fuel supplies to accomplish military missions and respond to possible foreign threats. I will discuss the issue of energy and national security below and argue that it is an important element of energy security though perhaps not in ways that policy makers often invoke it. For the purposes of this review I will define energy security as "the ability of U.S. households, businesses, and governments to accommodate disruptions of supply in energy markets." ${ }^{3}$

One area of general confusion related to energy security relates to energy consumption versus imports. This is most common in policy discussions related to oil dependence as typified by the quotation in footnote 1. Reducing oil imports is often viewed as an important policy imperative. The view is that reduced reliance on foreign oil suppliers will protect us from price shocks arising from foreign oil supply curtailments. The flaw in this reasoning is that oil is by and large a fungible commodity with oil prices equilibrating worldwide. Even if the United States imported no oil but rather relied on domestic production for all its oil needs, a supply shock elsewhere in the world would lead to a rise in domestic oil prices. This simply follows from the ability of domestic producers to divert oil from

\footnotetext{
${ }^{3}$ Many other approaches to defining and measuring energy security exist. Sovacool (2011), for example, defines an index along 20 dimensions with 200 attributes. In subsequent work, Sovacool \& Mukherjee (2011) reduce the number of dimensions to five and the number of attributes to 20. Sovacool (2013) applies the index to a set of countries and finds that Japan has the highest energy security index among the 18 countries considered. The impact of the Fukushima nuclear accident on Japan's energy system and economy suggest the difficulty with constructing robust energy security indexes.
} 
domestic markets to foreign markets as oil prices rise elsewhere. The domestic price will have to rise as well to re-equilibrate domestic supply and demand. ${ }^{4}$ Energy independence, properly understood, depends on reducing energy (or more specifically oil, in this context) consumption rather than imports.

A second area of potential confusion is the relationship between energy security and externalities. An economic externality is the impact of an economic agent's action on other agents that that is transmitted outside of market mechanisms. Pollution associated with energy consumption is a classic externality. In the absence of strong conditions on the ability of economic agents to bargain (see Coase, 1960) , markets outcomes will be inefficient. Efficiency requires that in equilibrium the social marginal benefits of energy use equal the social marginal costs. Assuming all benefits of energy use are private, efficiency is ensured when the price of energy equals its social marginal cost, the sum of private marginal costs of production and the external damages from energy use. One way to achieve an efficient market outcome is to set a tax equal to social marginal damages of pollution. Such a tax is called a Pigouvian tax (Pigou (1932)). Whether an energy security externality exists is an issue of some confusion. Following the logic of a recent report of the National Research Council (2009), I will argue that there is little if any externality associated with energy production or consumption arising from energy security considerations. The implication is that there is little potential for pareto improvements by levying an "energy security" tax on energy products ${ }^{5}$. This is distinct from concerns about energy security that may give rise to other policy responses. I discuss policy implications in section IV below.

\footnotetext{
${ }^{4}$ The U.S. government could prevent this by banning the export of domestically produced oil. This would be highly controversial and would simply lead to a redirection of oil investment from domestic exploration and development to foreign investment. This in the long run would also lead to domestic prices rising.

${ }^{5}$ This is true in a global sense. It is possible, as I discuss below, for a tax to improve domestic welfare at the cost of lowered welfare in other countries.
} 


\section{An Economic Perspective on Energy Security}

How important is energy in the U.S. economy? One metric is the amount of energy used per dollar of GDP in the US economy. Figure 1 graphs energy intensity (energy measured in BTUs per dollar of real GDP) from 1900 to the present.

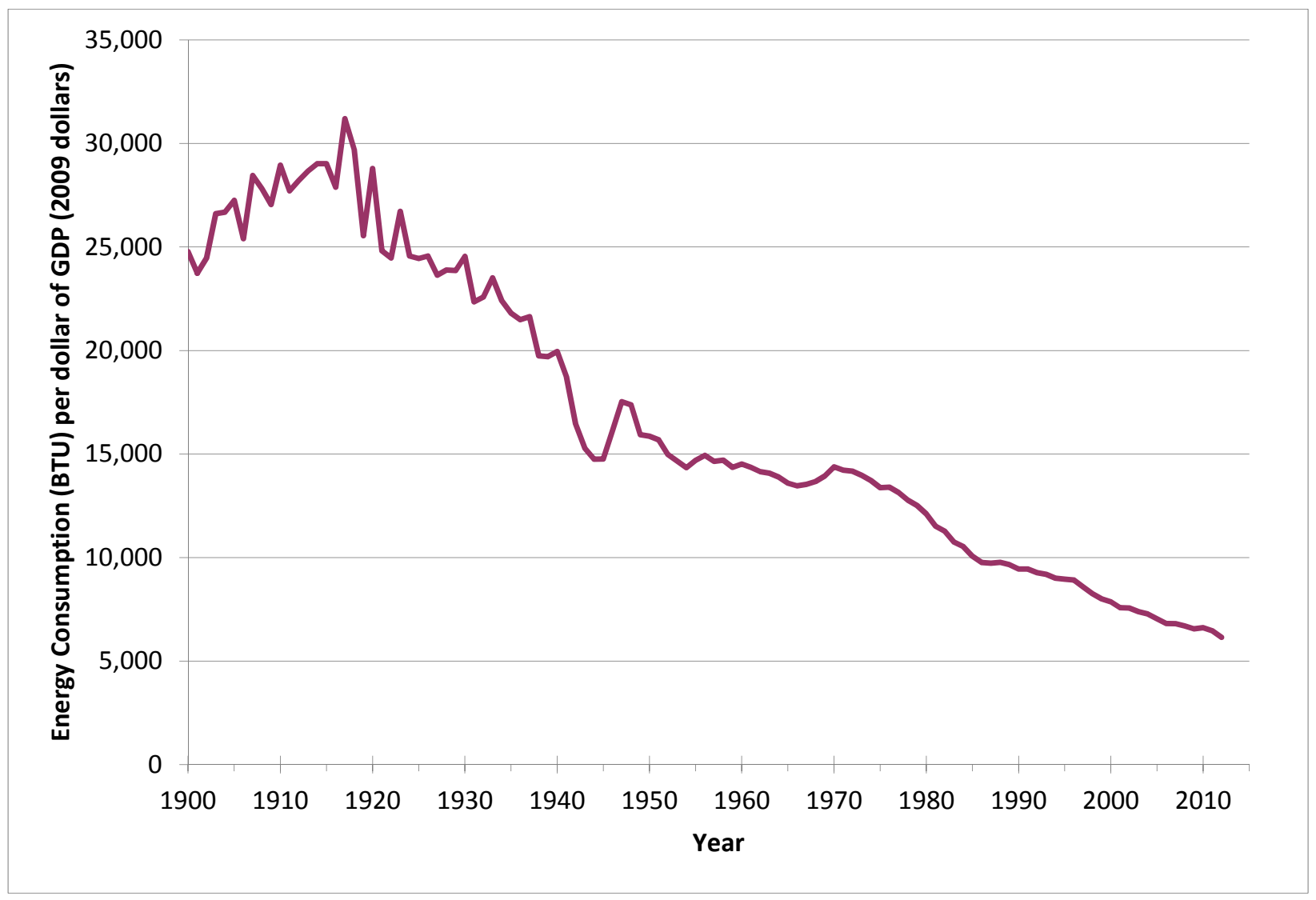

Figure 1: U.S. Aggregate Energy Intensity: 1900 to 2012

Source: GDP data from Federal Reserve Economic Data (FRED) series GDPCA. Prior to 1929 GNP data used from Schurr \& Netschert (1960), tabel XIII, p 524. Energy consumption data prior to 1949 from Schurr \& Netschert (1960) Table VII p 512, 1949-2011 from EIA Annual Energy Review table 1.3, 2012 from EIA Monthly Energy Review table 1.3

Energy intensity has fallen steadily from a peak of over 30,000 BTUs per dollar of real GDP in 1917 to a little over 6,000 in 2012, a decline of nearly 80 percent. Metcalf (2006) discusses the major drivers of the sharp decline in energy intensity over the last century. An important point emerging from Figure 1 is that improvements in energy intensity are not entirely a post-oil shock phenomenon. While energy 
intensity fell at a rate of $1.9 \%$ after 1970, it was falling at a rate of $0.9 \%$ between 1931 and 1970 . The acceleration in the rate of decline following the 1970 s oil shocks suggests the sensitivity of energy intensity to economic forces. ${ }^{6}$

Figure 1 obscures important differences among fuels. Oil, for example, is a dominant fuel for transportation while coal is primarily used in electricity production where it competes with natural gas and other sources. Figure 2 shows changes in energy intensity for petroleum, natural gas (NG), and coal between 1950 and 2011.

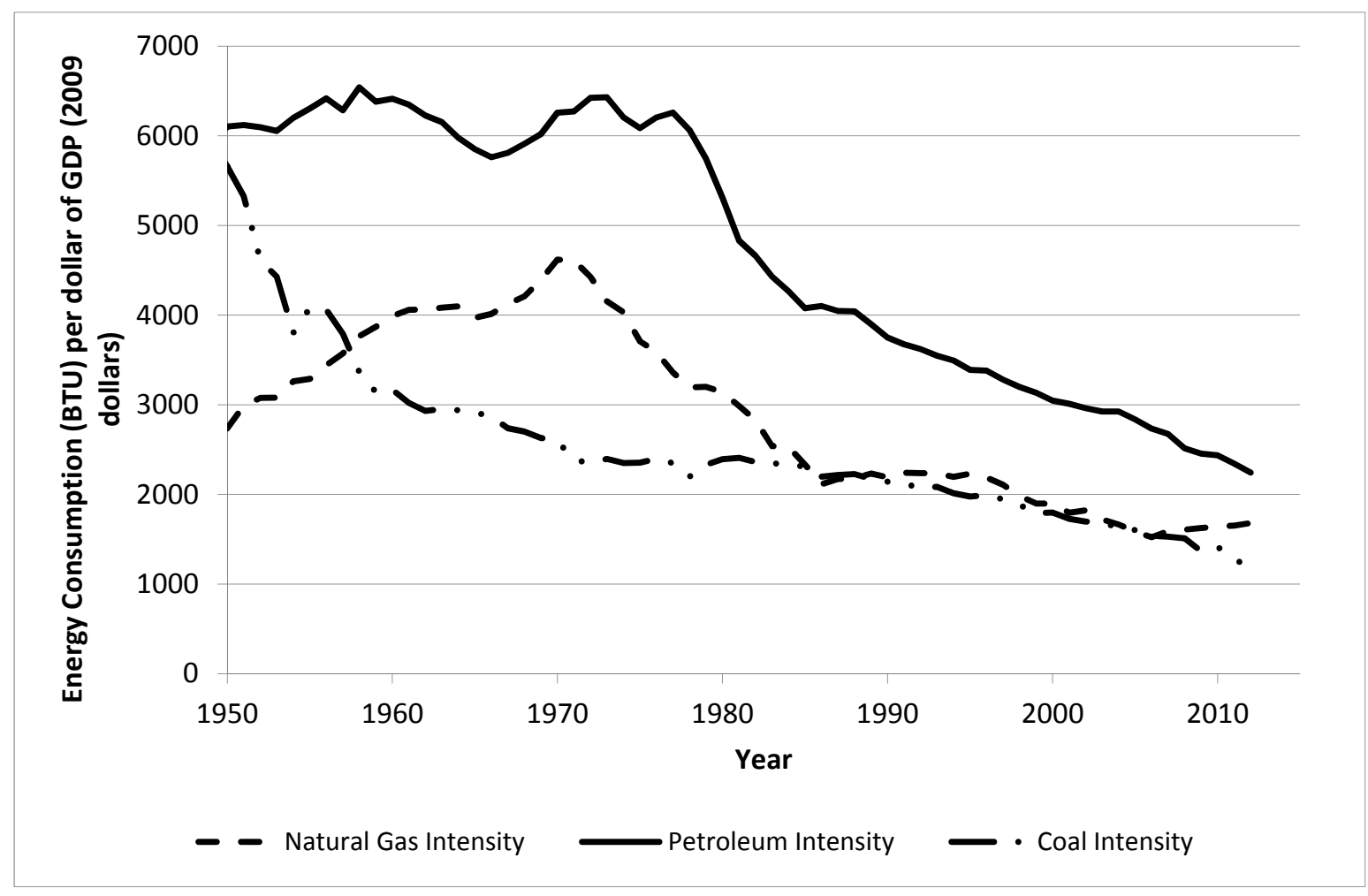

Figure 2: Fossil Fuel Intensity: 1950 - 2012

Source: GDP data from Federal Reserve Economic Data (FRED) series GDPCA. Energy consumption data up to 2011 from EIA Annual Energy Review table 1.3, 2012 from EIA Monthly Energy Review table 1.3

Petroleum intensity was over twice as high as NG intensity in 1950 but the intensity of the two fuels has nearly converged over the sixty year period. With the boom in domestic natural gas production along with more stringent fuel economy standards finalized in 2012, it is possible that petroleum intensity

\footnotetext{
${ }^{6}$ Metcalf (2008) explores the drivers of changes in energy intensity at the state level.
} 
could fall below that of natural gas within the decade. The intensity of coal use in 1950 was comparable to that of petroleum but has rapidly fallen between 1950 and 1980. Since then it has closely tracked the intensity of natural gas until the last five or so years with the hydrofracking boom in the United States.

These figures illustrate that our economy is significantly more efficient in using energy than before the first oil embargo. Holding other factors constant, this should make the United States less vulnerable to disruption in energy markets. This should not make us complacent, however, as the combination of the high oil prices in the mid 2000's along with the onset of the Great Recession demonstrated the ability of energy markets to harm the US economy as Hamilton (2009) argues.

Energy intensity is a useful metric for measuring improvements in energy efficiency. But what we really care about are measures of the impact on the economy of supply disruptions. I turn to that topic next. The literature on the economics of energy security has primarily focused on two key considerations: the impact of supply shocks on the economy and terms of trade effects associated with oil imports (Toman, 1993).

Supply Shocks and the Macroeconomy

I begin with a simple analysis of the impact of supply shocks on the U.S. economy due to Hamilton (2008). Consider a simple production function relating a firm's output to inputs:

$$
Y=F(K, L, E)
$$

Output $(\mathrm{Y})$ is a function of capital $(\mathrm{K})$, labor $(\mathrm{L})$, and energy $(\mathrm{E})$ used in the production of final goods and services. If output is sold at nominal price $p$, and the cost of inputs is $w, r$, and $q$ for labor, capital, and energy respectively then

$$
p Y=w L+r K+q E
$$

assuming constant returns to scale technology. Profit maximizing firms set the value of marginal product for each factor equal to the input price or

$$
p \frac{\partial Y}{\partial E}=q
$$


which can be rewritten as

$$
\frac{\partial \ln Y}{\partial \ln E}=\frac{q E}{p Y}
$$

The elasticity of the firm's output to energy use is equal to the share of energy in the firm's revenue. By analogy to the U.S. economy, a one percent curtailment in energy would be expected lead to a real output decline equal to the share of energy spending in GDP. Consider an oil supply shock. The historic share of oil expenditures in GDP (on percentage terms) is given in Figure 3.

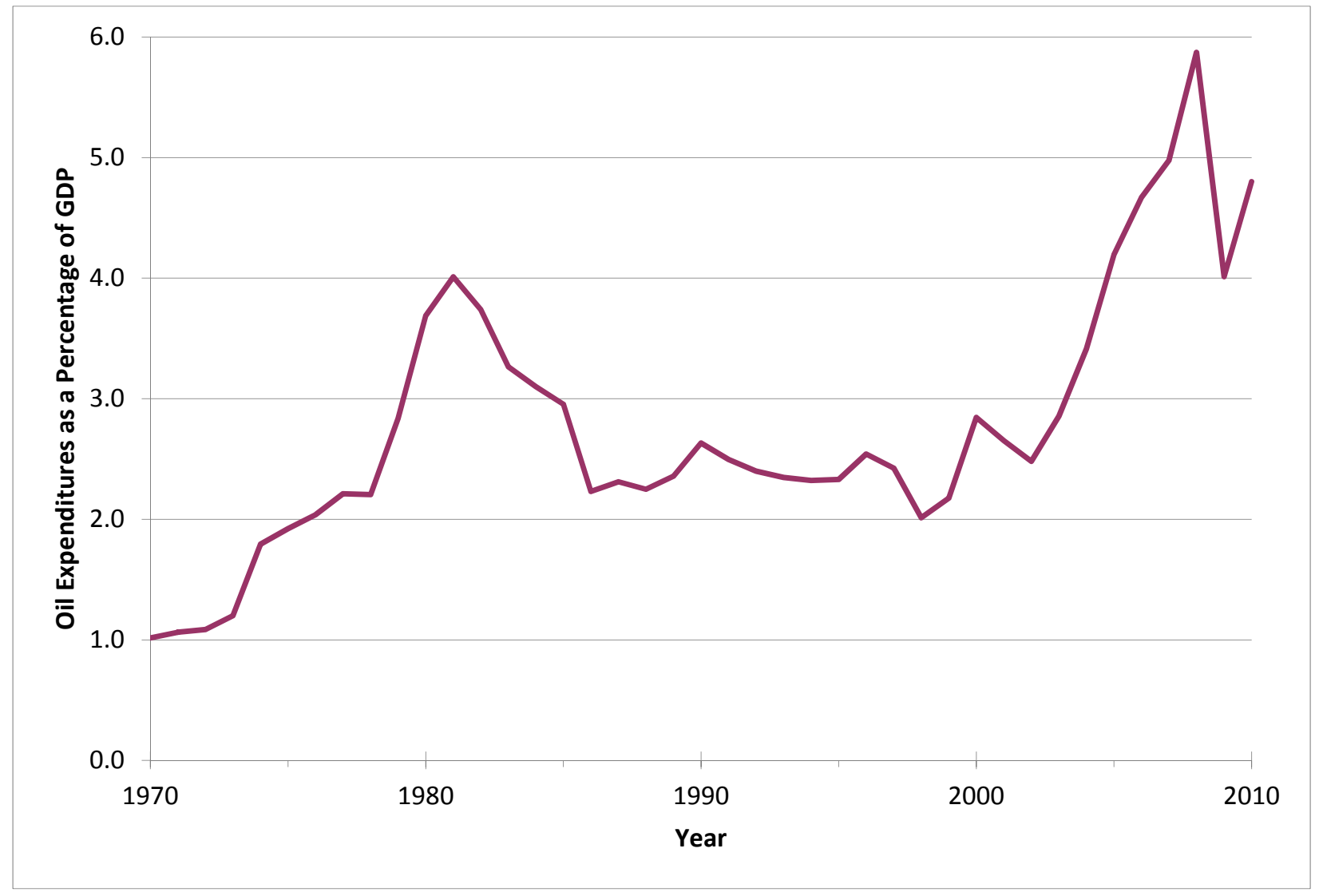

Figure 3: Share of Oil in GDP

Source: GDP data from Federal Reserve Economic Data (FRED) series GDPCA. Oil expenditure data from EIA Annual Energy Review table 3.5

The share has been in the 2 to 3 percent range except during price spikes. A 4 percent share is not unusual; the share rose to nearly 6 percent in 2008 but quickly dropped back. If we assume a 5 percent oil share (generous), then a supply shock of 10 percent should lead to a drop in the value of real output of .5 percent. 
Table 1 based on Hamilton (2008) shows a number of disruptions to world oil supply along with the associated impact on U.S. real GDP. Note that the counterfactual GDP growth is about 3.4 percent per year. So we're seeing an impact of a 7 to 10 percentage point supply curtailment on GDP in the range of 4 to 5 percent - an order of magnitude higher than what theory suggests should occur.

\begin{tabular}{|l|l|c|c|}
\hline \multicolumn{4}{|c|}{ Table 1. Exogenous disruptions in world petroleum supply, 1956-90 } \\
\hline Date & \multicolumn{1}{|c|}{ Event } & $\begin{array}{c}\text { Drop as \% of world } \\
\text { production }\end{array}$ & $\begin{array}{c}\text { Change in US real } \\
\text { GDP (\%) }\end{array}$ \\
\hline Nov. 1956 & Suez crisis & 10.1 & -2.5 \\
\hline Nov. 1973 & Arab-Israel war & 7.8 & -3.2 \\
\hline Nov. 1978 & Iranian revolution & 8.9 & -0.6 \\
\hline Oct. 1980 & Iran-Iraq war & 7.2 & -0.5 \\
\hline Aug. 1990 & Persian Gulf war & 8.8 & -0.1 \\
\hline Hamilton (2008) & \multicolumn{3}{|l}{} \\
\hline
\end{tabular}

One should not make too much of this simple analysis for a number of reasons including the lack of a carefully constructed counterfactual. But it is suggestive that oil supply shocks have outsized impacts on the economy. Hamilton (2008) discusses various explanations of this large impact of oil shocks on macroeconomic performance. The point worth making in this paper is that despite the small share of oil in GDP, energy in general and oil in particular can have large impacts on economic performance. Whether the impact of oil shocks on the economy is as large as it once was is a matter of considerable academic analysis. Analyses focus on factors such as the role of improved monetary policy response to oil shocks combined with a decreasing importance of oil in the economy (Nordhaus (2007)), the interplay between oil markets and other sectors (e.g. housing and automobiles) (Hamilton (2009) ), and the need to distinguish between supply and demand shocks (Kilian (2008)). Despite (or perhaps because) of the lack of consensus among economists on the macroeconomic impact of energy supply shocks, policy makers place great importance on supply stability as an economic stabilizing force.

\section{Energy Imports}

The reliance on imported oil in the United States has historically been a source of concern with respect to energy security. The notion of an energy security price premium is associated with the 
potential monopsony power of U.S. consumers in aggregate. The United States makes up some 20 percent of global oil consumption. The increased demand for one more barrel of oil by a large consumer drives up the world price of oil and so raises the cost of all inframarginal barrels of imported oil. Thus the social (from a U.S. point of view) cost of oil is the price of oil along with the incremental cost of oil imports from this marginal import. ${ }^{7}$ Because the United States is such a large consumer, any U.S. policy to reduce domestic oil demand reduces the world oil price and benefits the US through lower prices on inframarginal oil imports. Setting a tax on oil equal to the price wedge, so the argument goes, would "internalize" this apparent externality.

Figure 4 illustrates how such a tax would work. ${ }^{8}$ The aggregate demand for oil is given by the downward sloping curve marked D. With an upward sloping supply curve for oil, the market equilibrium occurs at point $e$ where $Q_{0}$ barrels of oil are consumed at price per barrel $P_{0}$. A domestic tax of $f h$ shifts the oil demand curve from $D$ to $D^{\prime}$ and leads to a drop in the world oil price from $P_{0}$ to $P_{1}$. The gain to consumers from the fall in oil price is the rectangle $P_{0} P_{1} f g$. This is offset by losses to producers in oil revenue (equal to the same rectangle). If all supply comes from domestic production, there is no gain to the US. The gain to producers is exactly offset by the loss to US producers. If all supply comes from non-US producers then the gain to US consumers is financed by a transfer from other oil-producing countries. The marginal oil premium is the incremental income transfer to US consumers from foreign producers from a small reduction in demand for oil arising from a US oil consumption tax.

\footnotetext{
${ }^{7}$ The concern here is with imports since a rise in the price of domestic oil simply induces a transfer from one U.S. resident to another.

8 This discussion draws heavily on the discussion in NRC (2009). The author served on the panel writing that report and was a member of the subgroup focusing on energy security issues.
} 


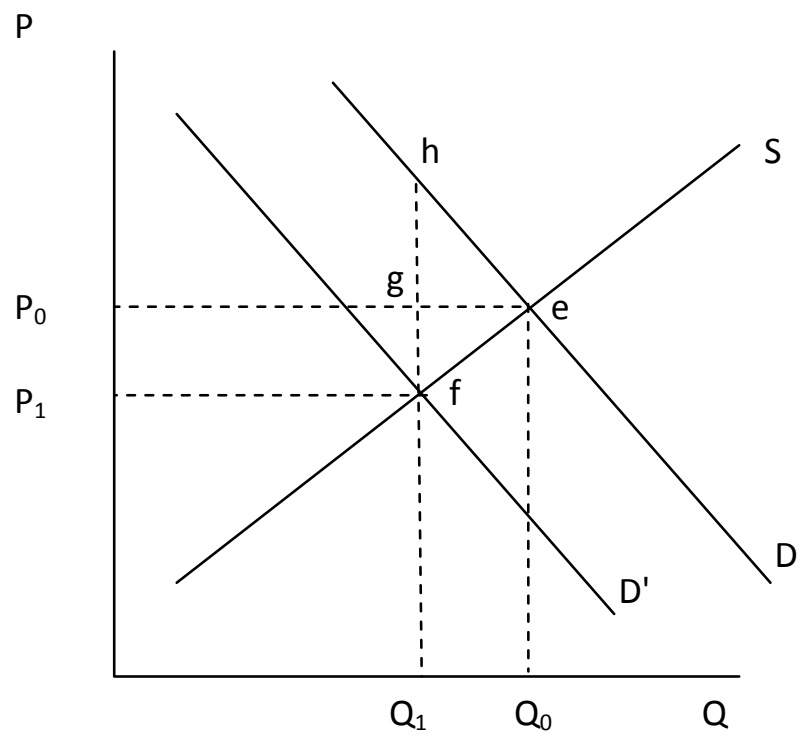

Figure 4. Monopsony Power

A policy to take advantage of consumer purchasing power generates a transfer from foreign oil producing nations to the United States. Such a "beggar thy neighbor" policy has been justified on the grounds that OPEC is artificially inflating world oil prices at the expense of consuming nations and that the exercise of monopsony power is a countervailing policy (e.g. Broadman \& Hogan, 1988). This is an example of a pecuniary externality (Bohi \& Toman, 1993).

The steady and rapidly rising share of oil imports in consumption in the post-war period (Figure 5) combined with the 1973 Arab oil embargo certainly helps explain interest in the monopsony pricing argument. Reliance on foreign oil peaked in 2005 and has fallen by roughly 15 percentage points since then with the boom in domestic oil production. 


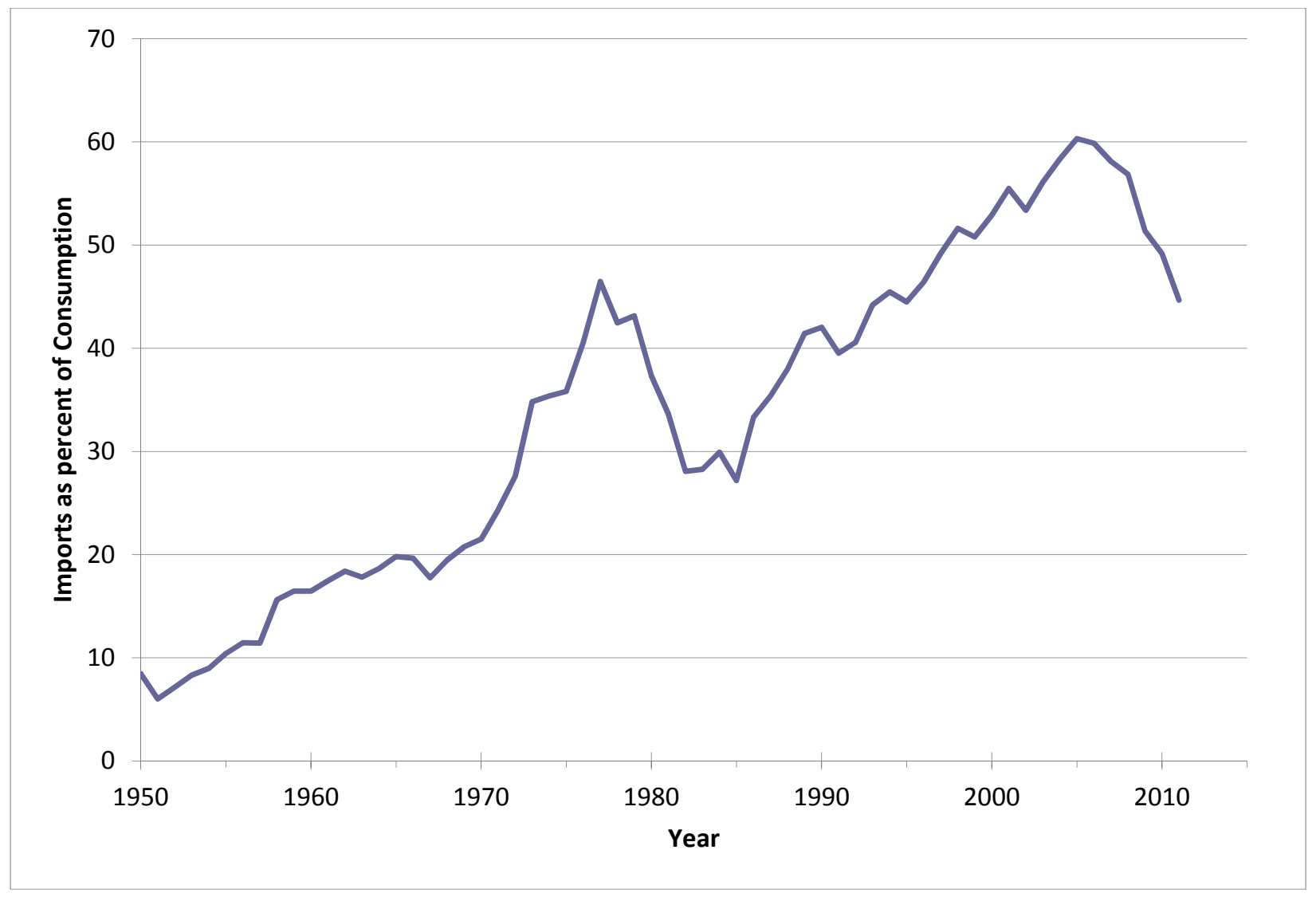

Figure 5. U.S. Oil Imports as a Percentage of Oil Consumption

Source: Net Petroleum Imports and total Petroleum Consumption from EIA AER 5.1a

The National Research Council (2009) report on energy externalities considered in some depth whether the market power of large consumers should be viewed as an externality. The report notes that "[e]xternalities create a market failure. Exercising monopsony power creates a market failure where one did not exist before." (р. 329). The report goes on to raise the issue of supplier response to the exercise of market power by consumers. A dominant producer or cartel might choose to withhold supply from the market to act as a countervailing force to the price depressing behavior of monopsonists. Whether an effective cartel exists that could exercise this power is an empirical matter. Adelman (1980) argued that OPEC does not function with sufficient effectiveness to offset monopsony behavior with any precision. Alhajji \& Huettner (2000) find evidence of Saudi Arabia serving as a dominant producer in the 1973 to 1994 period but do not find evidence of cartel behavior by OPEC. 
Perhaps more to the point, monopsony behavior per se does is not related to the notion of energy security as defined in this paper. Any policy that reduces consumption of an energy source, here oil, enhances the ability of U.S. households, businesses, and government to accommodate disruptions of supply in energy markets. But the transfer of rents, the goal of the exercise of monopsony power, does not itself enhance our ability to accommodate supply disruptions.

Responsiveness to Market Shocks

The policy focus on energy security stems from society's inability to find ready substitutes for energy in the production of goods and services valued by consumers. More precisely the elasticity of demand for energy is low. Combined with a low short run price elasticity of supply, small fluctuations in supply and demand can have large price impacts. Consider the summer of 2008 when oil prices spiked to an all-time high of over $\$ 145$ per barrel (July 3 West Texas Intermediate Crude price data from U.S. Energy Information Administration (2013a)). This represented a nearly 50 percent increase in price over the previous six months and sparked considerable policy discussion about the possible role of speculators in driving up oil prices. Simple demand and supply theory may help explain the price spike. A supply shortfall (in percentage terms) of $\Delta$ would require a percentage price increase of $\delta$ to equilibrate supply and demand where

$$
\delta=\frac{\Delta}{\epsilon_{S}-\epsilon_{D}}
$$

and $\varepsilon_{S}$ is the price elasticity of supply and $\varepsilon_{D}$ is the price elasticity of demand. The short run elasticities of supply and demand for oil are on the order of .05 and -.05 respectively (see survey in Smith (2009)). Based on these elasticity estimates, a 5 percent shortfall in supply (roughly 4 million barrels per day (bpd) in 2008) would require a fifty percent price increase to reduce demand and increase supply sufficiently to clear the market. Smith (2009) documents a number of supply shocks in early 2008 that quickly get us in the neighborhood of 4 million barrels a day of reduced supply. Oil speculation may or may not be an issue in contributing to price volatility, but very small short run supply and demand 
elasticities can contribute to very large short run price changes in response to modest supply curtailments.

The ability of households, businesses, and government to react to disruptions in supply varies significantly across fuels. Petroleum accounted for 93 percent of transportation fuels in the United States in 2012 highlighting the limited substitutability of other fuels for oil in this sector. ${ }^{9}$ While electric vehicles are making inroads into the transport sector, they will not play a significant role in the short run in shifting away from petroleum towards electricity (from natural gas, coal, or other sources). In contrast, coal and natural gas accounted for 41 and 24 percent of electricity production respectively in 2012. Flexibility in dispatch along with new generating capacity mean that the elasticity of substitution between natural gas and coal is much higher in electricity production than between oil and any other fuel in the transport sector. As a result households and businesses are less susceptible to supply disruptions given the opportunities for fuel substitution in the near term. ${ }^{10}$

The vulnerability to fuel disruptions varies across countries for given fuels. Just over 20 percent of electricity was produced from nuclear power in 2012. Short-term disruptions to nuclear electricity production can be quickly replaced by other sources in the United States. The Congressional Budget Office (2012) noted that the August 2011 earthquake in the eastern United States caused two nuclear power plants to shut down temporarily. While power prices spiked by more than 50 percent in the short run, costs fell back to pre-earthquake levels very quickly (CBO, p. 13). Contrast this with the situation in Japan following the Fukushima accident. Prior to the March 2011 tsunami that ultimately destroyed units $1-4$ of the Fukushima Daiichi nuclear complex, Japan was generating some 30 percent

\footnotetext{
${ }^{9}$ Data in this section taken from U.S. Energy Information Administration (2013b)

${ }^{10}$ This is true in general. But local bottlenecks may need attention. Despite the wide availability of natural gas, some sections of the country may face energy supply vulnerabilities due to specific circumstances. New England, for example, has two major pipelines bringing natural gas into the region. These pipelines operate at near capacity and electric generating plants have a lower level of priority to gas than do households and businesses. Thus New England is vulnerable to natural gas related electricity shortages in periods of extreme cold. The independent system operator for New England (ISO-NE) has identified this as one of three significant challenges facing the system. See ISO New England (2013).
} 
of its electricity from nuclear power with plans to raise that percentage to 40 percent by 2017 (see World Nuclear Association (2013)). Instead, Japan has gradually shut down all of its nuclear power plants and the process of restarting them is uncertain and subject to considerable regulatory and political delay. Japan has scrambled to replace the lost electricity and has increased its imports of liquefied natural gas (LNG) and oil for electricity generation. Natural gas imports rose by 11 percent and oil imports by 2 percent after the accident. The natural gas imports cost nearly $\$ 70$ billion - double the cost of imports the previous year - and contributed to the largest trade deficit in Japan's history (Nakano (2013)). Meanwhile stringent energy conservation programs were put into effect and Japan reduced its electricity consumption by 12 percent in the summer of 2011 (relative to 2010) and peak demand by 18 percent. See Hayashi \& Hughes (2013) for an analysis of policy responses in Japan to the disaster.

\section{Non-Economic Energy Security Considerations}

\section{Supply Security}

Above I have argued that the share of imported oil in domestic consumption is unrelated to the vulnerability of U.S. consumers to oil price shocks. That is not to say, however, that the security of supply is an unimportant concern. While oil prices might adjust near instantaneously to a shortfall in supply somewhere in the world, the ability of any single country to balance supply and demand throughout the system may be difficult. The United States, for example, imported 10.5 million barrels of petroleum products a day in 2012 (see BP (2013)). Over half of imports came from Canada (28 percent) and Latin America (28 percent). Disruptions in oil supply from Canada, for example, could put pressure on suppliers to meet demand at refineries in the upper Midwest.

The limited ability to respond to supply-demand imbalances in the United States market is reflected to some extent by the price spread between Brent oil and West Texas Intermediate (WTI) oil. Historically, WTI has traded at roughly par with Brent oil. Starting in 2011, Brent oil began to trade at a 
significant premium peaking at nearly $\$ 30$ a barrel in September, 2011 (a premium of 30 to 35 percent over the WTI spot price). The spread was caused in part by an inability to move oil from Cushing Oklahoma, where WTI is priced, to Gulf of Mexico refineries or refineries in other parts of the country. A combination of pipeline capacity expansions, reversal of flow in a key pipeline from West Texas oilfields to the Gulf of Mexico and increased use of rail to move oil has reduced the spread (Pan (2013)).

Whether price fluctuations due to regional supply demand imbalances constitute a significant security problem is not clear. One could reasonably view the price differentials as important market signals to spur needed investment in pipeline capacity and other capital to re-equilibrate the market.

\section{Energy Infrastructure}

Energy related capital constitutes a significant share of non-residential fixed assets. Table 2 reports the net stock of energy related non-residential fixed assets in 2012.

\begin{tabular}{|l|r|r|}
\hline \multicolumn{3}{|c|}{$\begin{array}{c}\text { Table 2. Current Cost Net Stock of } \\
\text { Non-Residential Energy Fixed Assets: } \mathbf{2 0 1 2}\end{array}$} \\
\hline Category & $\mathbf{2 0 1 2} \mathbf{\$}$ billions \\
\hline Equipment and Software & 108.9 & 691.5 \\
\hline Engines and turbines & & \\
\hline $\begin{array}{l}\text { Electrical transmission, distribution, and } \\
\text { industrial apparatus }\end{array}$ & 459.3 & \\
\hline $\begin{array}{l}\text { Mining and oilfield machinery } \\
\text { Electrical equipment, nec }\end{array}$ & 26.1 & \\
\hline Power & $1,671.5$ & $3,311.4$ \\
\hline Mining exploration, shafts, and wells & $1,322.8$ & \\
\hline Federal Power & 14.1 & \\
\hline State and Local Power & 303.0 & \\
\hline \multicolumn{2}{|c|}{ TOTAL } & $\mathbf{4 , 0 0 2 . 9}$ \\
\hline $\begin{array}{l}\text { U.S. Bureau of Economic Analysis (2013), Fixed Asset Account Tables 2.1, } \\
\text { 7.1B, 4.1. }\end{array}$ \\
\hline
\end{tabular}

Non-residential energy fixed assets were valued at $\$ 4$ trillion in 2012 . This represents 12.5 percent of total non-residential fixed assets and is primarily comprised of structures (electric generating and 
mining). ${ }^{11}$ While not the focus of most economic analyses of energy security, security of energy capital is a significant concern for policy makers and private firms. A 2013 Presidential Policy Directive designates sixteen critical infrastructure sectors of which energy is one (Office of the President (2013)). ${ }^{12}$ The focus of the directive is to "strengthen the security and resilience of its critical infrastructure against both physical and cyber threats" (Office of the President (2013), p. 2). In developing an energy sectorspecific plan, the Departments of Homeland Security and Energy focused on ensuring a "robust, resilient energy infrastructure in which continuity of business and services is maintained" (U.S. Departments of Homeland Security and Energy (2010), p. 1). The plan focuses on information sharing across government agencies and the private sector, physical and cyber security, coordination and planning, and strengthening of public confidence.

The National Research Council (2009) (NRC) report considered to what extent U.S. energy infrastructure was vulnerable to accidents and terrorist attacks, focusing particularly on liquefied natural gas (LNG) facilities, oil spills from ships, oil and gas pipelines, and nuclear power plants. Citing Parfomak \& Vann (2009), the NRC study concluded that the risk of incidents was quite small. The focus on LNG facilities came at a time when dramatic growth in the number of LNG regasification facilities was expected. The boom in shale gas production in the United States has led to a marked shift away from import towards export facilities and FERC is currently considering a number of applications either to build new export facilities or convert import to export facilities. ${ }^{13}$

The NRC study focus on spills from ships and oil and gas pipelines followed from the study's focus on externalities associated with energy production and consumption. Little, if any, concern was

\footnotetext{
${ }^{11}$ The share of private non-residential energy fixed assets in total private non-residential fixed assets is 18.5 percent. These estimates do not include the value of power equipment in the U.S. military, transportation related assets, or residential energy related capital and durable goods. Non-residential transportation equipment and residential motor vehicle durable goods adds $\$ 2.46$ trillion to the figure in the table.

${ }^{12}$ President George W. Bush issued the original critical infrastructure presidential directive in 2003 (Office of the President (2003)). PPD-21 is an update to that directive.

${ }^{13}$ According to the Federal Energy Regulatory Commission (2013) website, accessed Nov. 5, 2013, three import facilities have been proposed to FERC and 13 export facilities proposed. There are currently no operating export terminals in the United States.
} 
focused on energy security issues. Security issues are viewed as significant by policy makers in the operation of nuclear power plants. Holt \& Andrews (2012) recount industry requirements set forth in the Energy Policy Act of 2005 (P.L. 109-58) for more extreme Design Basis Threats (DBT) that a nuclear power plant must be able to repel. Plants are required to conduct mock attack exercises at least once every three years. According to Holt \& Andrews, 136 mock attacks had been carried out by the end of 2010 with 10 resulting in the simulated destruction of the nuclear facility. The Nuclear Regulatory Commission (NRC) responded with enhanced security requirements for all nuclear facilities.

In addition to possible terrorist attacks, the NRC ordered all nuclear power plants to develop security plans to address damages that could result from an aircraft crashing into the facility, whether accidental or deliberate. The storage of spent fuel at existing nuclear power plants is another area of concern for the NRC given the failure to establish a national repository for spent nuclear fuel.

Cybersecurity is increasingly a concern for nuclear power plants and other energy infrastructure, especially after the release of the Stuxnet virus caused significant damage to the Iranian nuclear program in 2010 and raised concerns about state sponsored cyber-attacks on energy and other critical infrastructure. The Department of Homeland Security's Industrial Control Systems Cyber Emergency Response Team (ICS-CERT) flagged 198 cyber incidents in FY2012 with the energy sector facing the largest share (41 percent) (Department of Homeland Security (2012)). The Nuclear Regulatory Commission (2009) released cybersecurity regulations and a subsequent regulatory guide for the program the following year. Little economic analysis has been undertaken on the issue of cybersecurity. Kobayashi (2005) argues that much of the research and information on cybersecurity has the character of public goods and is thus socially underprovided by the private sector.

Conceptually, energy infrastructure is no different than any other form of infrastructure that is vulnerable to attack by terrorists or countries with whom the United States is in conflict. For any type of critical infrastructure, the important question is how resilient the system is to attack. One aspect of 
resilience is the ability of the system to work around damaged or destroyed infrastructure. If the Holland Tunnel from New Jersey to New York City were unexpectedly closed, considerable disruption would ensue. But some vehicles would adapt by shifting to other bridges and tunnels out of Manhattan while other commuters would substitute into trains, ferries, and other modes of transportation. Similarly with damage to oil or natural gas infrastructure. Electrical grids, on the other hand, may not have the same degree of resilience. Electricity differs from other commodities in the need for supply to be balanced by demand at all points throughout the system at all times. Failure to balance supply and demand can lead to grid failures. It is for this reason that grid operators require redundancy in the system to anticipate potential failures, accidental or otherwise.

This sensitivity of electrical transmission and distribution systems to failures that can cascade was dramatically made clear in August, 2003 when tree branches in Ohio brought down a power line, only to have the resultant power surge bring down transmission systems from the Midwest through the Northeast. Ultimately, 50 million people lost power at an estimated cost of nearly $\$ 10$ billion, according to DiSavino (2013). ${ }^{14}$ DiSaviano notes that a combination of stronger mandatory standards, fines, training, and improved equipment have reduced the risks of such a large black out. But the fact remains that the electrical transmission and distribution system is perhaps the most fragile energy infrastructure. Energy and National Security

U.S. reliance on oil contributes to high oil prices that support a number of unstable governments as well as governments with interests at odds with the United States. This has long been recognized (c.f., Deutch \& Schlesinger, 2006). The implications for national security are less clear cut. Reducing oil consumption (as opposed to oil imports) might lessen the influence of oil rich countries. But it might not materially affect military and strategic thinking. As the NRC report notes, our presence in the Middle East not only safeguards oil transport routes and oil producing regimes but also contributes to political

\footnotetext{
14 Anderson \& Geckil (2003) estimate an economic loss of $\$ 6.4$ billion with most of that due to lost wages and
} profits. Using an input output model, Anderson et al (2007) estimate a similar cost impact. 
goals such as fighting terrorism and providing support for Israel. Noting the work of Bohi \& Toman (1993), the NRC report concluded that the marginal cost of oil related military spending is essentially zero. In other words, a marginal (or even inframarginal) reduction in oil consumption might not affect our national security planning or spending significantly.

To be clear, energy is an integral part of military readiness and a critical military input. One of the lessons from the wars in Iraq and Afghanistan is the importance of fuel conservation given the logistical difficulties of maintaining supply lines. But this is simply a military logistical issue similar to the countless other logistical supply concerns the military grapples with on a daily basis.

\section{Energy and Foreign Policy}

The NRC report identified a number of channels through which domestic energy consumption affected foreign policy. First, petrorevenues support regimes, many of which have foreign policies at variance with the United States (viz Iran and Venezuela). States may also eschew economic assistance tied to reforms designed to promote greater political and economic openness. This creates difficulties for the United States internationally but is not, as the NRC report noted, an externality associated with energy consumption. Second, the report pointed out that U.S. oil consumption may constrain foreign policy citing a 2006 report by the Council on Foreign Relations noting that oil dependence can induce political realignments that constrain the ability of the United States to form partnerships to achieve common objectives. Perhaps the most pervasive effect arises as countries dependent on imports subtly modify their policies to be more congenial to suppliers. For example, China is aligning its relationships in the Middle East (e.g. Iran and Saudi Arabia) and Africa (e.g. Nigeria and Sudan) because of its desire to secure oil supplies. (Deutch \& Schlesinger (2006), pp. 26-27).

These are important political issues for which economists are not well equipped to provide an economic assessment. Are there economic costs economists can identify associated with constraints on 
foreign policy associated with our energy consumption or other countries' production levels? That is an area of potential research that to date has not been examined.

\section{Energy Security Policy Instruments}

Energy security is often invoked as a rationale for a number of policy measures. Most sensible policies focus on reducing the risk of disruptions in supply and the impacts of supply disruptions. Measures that contribute to increasing the elasticity of supply and demand for energy are also useful as they reduce the price volatility associated with shifts in demand and supply.

\section{Policies to Reduce Energy Intensity}

The United States has made dramatic improvements in the efficiency with which it uses energy. Energy intensity, as noted above, has been cut roughly in half since 1973. Many energy efficiency policy proposals have positive net present value, especially when one accounts for local and global externalities associated with the use of fossil fuels. Gillingham et al (2009) catalog a list of potential market and behavioral failures that would justify energy efficiency policies. Broadly speaking the market failures include environmental externalities and lack of marginal cost pricing for electricity, capital market constraints, innovation spillovers in efficiency innovation, and insufficient and asymmetric information. The authors note that the literature is not settled on the extent of market failures and the most appropriate policies to address the most significant of the hurdles to efficient energy efficiency investments. Pricing externalities or regulating emissions raises the price of energy and directly stimulates increased energy efficiency investments. Public funding for research and development is likely to counteract socially sub-optimal investments in R\&D. But this is true of R\&D in general and not limited to energy related innovations. Moreover, the share of social - as opposed to private - benefits of R\&D in total benefits falls as we move downstream from pure research to technology innovation to deployment. Public policy often focuses more on downstream research, development, and deployment where private benefits are most easily captured by firms. In addition, directed R\&D runs the risk of 
picking technologies that don't have the highest return on investment. Focusing on supporting pure research across the board is likely to support research with the greatest amount of positive spillovers. Policies to Encourage Energy Diversity

Diversity in the fuels consumed provides benefits in the form of dampened impacts of supply shocks on prices and economic activity. If the share of petroleum in the mix of energy sources is reduced, any oil related supply reduction will have a smaller impact on the economy. While an increase in oil prices would also presumably lead to an increase in the price for substitutes to oil (depending on the elasticities of substitution between oil and other energy sources), the overall energy price increase will be lower with a lower share of oil in the energy mix.

Diversity in supply sourcing is often cited as an energy security issue. The economic security benefits of diversification on this dimension are less clear cut. To the extent that energy sources trade in world markets, supply shortfalls from one supplier can be made up by purchases from other suppliers. Increasing the number of potential energy suppliers overall has benefits in reducing market power among suppliers. But it is not clear that increasing the number of supply sources for an individual country is especially beneficial.

\section{Infrastructure investment}

Adequate infrastructure is critical to the reliability of energy supply. New England, for example, has seen a surge in the planning and construction of natural gas fired electricity generating units at a time when existing pipelines to bring natural gas into the region are near capacity and raise concerns about potential supply shortfalls (ISO New England (2013)). High voltage electricity transmission lines are also needed to match the growth in supply of new generating sources and, more critically, to handle the increased amounts of variable load from wind and other variable sources. There was considerable concern in the recent past over obstacles to new investments in cross-state high voltage transmission, the type of capital needed to move wind power from high-wind, low-density 
regions to urban areas where electricity demand is high (Metcalf (2010a)). High voltage transmission construction has picked up since the 2004-2008 period with the number of miles added of 200kV lines or higher more than doubling between the 2004-08 period and the 2008-12 period (North American Reliability Council (2012), p. 37). The government's role in promoting infrastructure investment is more in the area of planning and coordination rather than financing investment. ${ }^{15}$

\section{Stockpiling}

After the 1973-4 oil embargo, Congress created the Strategic Petroleum Reserve (SPR), designed to contain sufficient oil to cover 90 days of net imports (Andrews \& Pirog (2012)). Congress authorized the physical storage of 750 million barrels in 1978 and expanded capacity to 1 billion barrels in 2005 though current capacity is limited to 727 million barrels. Currently the SPR contains just under 695 million barrels (U.S. Energy Information Administration (2013b)). SPR drawdowns are authorized upon a presidential finding that a "severe energy supply interruption" exists or is imminent (Andrews \& Pirog (2012), p. 3). SPR releases have been authorized in the face of international political crises (1990 invasion of Kuwait by Iraq and the subsequent Desert Storm response, 2011 Libyan supply shortfalls due to civil war) as well as domestic weather related supply curtailments (2005 Hurricane Katrina). In addition, 23 million barrels were sold in 1996 to finance deficit reduction in the Clinton Administration. The deficit reduction sale was controversial and Obama Administration proposals to reduce the deficit have not been taken up by Congress (Andrews \& Pirog (2012)).

The SPR is controversial on several levels. First, there are concerns that presidents may try to use SPR additions and withdrawals in an effort to manipulate oil prices. Second, it is not clear that the existence of the SPR appreciably affects world oil prices. Any drawdown large enough to affect world prices would dramatically deplete reserves and could be offset by producer supply curtailments

\footnotetext{
${ }^{15}$ The federal government does support transmission and other infrastructure investments through accelerated tax depreciation. The tax treatment of electricity transmission lines, however, is significantly less generous than the treatment of other energy assets. See Metcalf (2010b).
} 
(Considine (2006)). Other issues include the rate at which oil can be withdrawn from the SPR stocks and the concentration of reserves in one part of the country (Gulf of Mexico area). Finally, there have been concerns that the type of oil stored in the SPR is not consistent with the types of crude that refineries are designed to process (Andrews \& Pirog (2012)).

International Coordination

The International Energy Agency (IEA) was established in the aftermath of the 1973-74 oil crisis in part to coordinate energy supply and demand activities among OECD countries. One of its activities is to coordinate strategic petroleum reserves management. IEA, for example, requires members to stockpile oil to cover at least 90 days of net imports and to maintain measures to coordinate with other IEA members in the face of oil supply disruptions. the IEA, for example, coordinated the 2011 release during the Libyan civil war. While China, India, and other major developing countries are not part of the OECD, and therefore not eligible for membership in the IEA, the IEA increasingly works closely with many of these countries to coordinate supply and demand issues.

\section{Taxes and Subsidies}

Taxes can be used to raise the price of energy and so discourage consumption, thereby contributing to a lower energy intensity in the economy. Higher taxes in the short run affect consumer behavior directly by encouraging less use and in the long run contribute to a more energy efficient capital stock. The difference in vehicle fuel efficiency between the United States and Europe is due to a number of factors but the higher gasoline and diesel prices in Europe are certainly an important factor. Subsidies to new energy sources (e.g. wind and solar) can also contribute to a more diversified energy supply system. Finally, removing subsidies to fossil fuel production in the United States would raise the price of energy and so discourage energy use. Metcalf (2007) notes, however, that removing all tax incentives for fossil fuel production in the United States is unlikely to raise oil prices by more than about 0.4 percent. A carbon tax would also discourage energy consumption but will dampen coal 
consumption substantially more than oil and natural gas consumption. While this would have significant environmental benefits (both in terms of local air pollution and greenhouse gas emissions), it is unlikely to have significant energy security benefits unless the tax is sufficiently high as to shift us from a petroleum and fossil fuel based economy to a non-fossil fuel economy. Without a clear understanding of what the energy mix would be in this new world, it is difficult to conjecture the energy security implications of this shift.

\section{Conclusion}

Energy security is the ability of U.S. households, businesses, and government to accommodate disruptions of supply in energy markets. The literature on the economics of energy security is thin and has focused in large measure on measuring the externalities associated with energy security. That focus is misplaced in my view. The real energy security issues may be more micro in nature. This includes such issues as the costs of bottlenecks in specific locations (e.g. Japan following the Fukashima nuclear power accident or natural gas in supply bottlenecks in New England).

Future research on this topic might well benefit from considering the following questions. First, what are the network spillovers from private investments in electricity transmission lines and to what extent are they captured by investors? Theoretical analysis private investment in transmission indicates a number of possible market failures (see Joskow \& Tirole (2005)) but there is little empirical analysis. Second, what are the economic costs of electricity supply disruptions? While there has been extensive work on the macroeconomic costs of oil price shocks (e.g. Kilian (2008), Hamilton (2009), Kilian (2009)), analysis of major and minor electricity blackouts is less extensive. ${ }^{16}$

Third, how can we reconcile differences in attitudes towards energy security between economists and policy makers? This may perhaps be the most important question of all. Once one goes beyond the literature on energy security externalities discussed above, there is little focus by

\footnotetext{
${ }^{16}$ Recent work includes Fisher-Vanden et al (2012) and Leahy et al (2012) in addition to Anderson et al (2007).
} 
economists on this topic. Meanwhile, it has been a serious focus of policy makers since the 1973 Arab oil embargo (if not earlier). One possible explanation is that some of the energy security concerns relate to non-quantifiable spillovers into areas such as foreign policy. Here political scientists and scholars in international studies may find institutional and qualitative analysis more useful. But it may be that their work can be helpfully augmented by more economic analysis than is currently taking place.

It may also well be that policy concerns are more about policy coordination and planning which while important are not natural areas of study for economists. In addition, concerns about ensuring the safety of energy supply chains are more the domain of military logistics and security than economics.

But it may also be that there are unexplored areas for economists to develop new research programs. 


\section{References}

Adelman MA. 1980. The Clumsy Cartel. The Energy Journal 1: 43-52

Alhajji AF, Huettner D. 2000. OPEC and World Crude Oil Markets from 1973 to 1994: Cartel, Oligopoly, or Competitive? The Energy Journal 21: 31-60

Anderson CW, Santos JR, Haimes YY. 2007. A Risk-based Input-Output Methodology for Measuring the Effects of the August 2003 Northeast Blackout. Economic Systems Research 19: 183-204

Anderson PL, Geckil IK. 2003. Northeast Blackout Likely to Reduce US Earnings by \$6.4 Billion, Anderson Economic Group, Lansing MI

Andrews A, Pirog R. 2012. The Strategic Petroleum Reserve: Authorization, Operation, and Drawdown Policy. Rep. R42460, Congressional Research Service, Washington, DC

Bohi DR, Toman MA. 1993. Energy Security: Externalities and Policies. Energy Policy: 1093-109

BP. 2013. BP Statistical Review of World Energy June 2013. bp.com/statisticalreview

Broadman HG, Hogan WW. 1988. The Numbers Say Yes. The Energy Journal 9: 7-30

Coase R. 1960. The Problem of Social Cost. Journal of Law and Economics 3: 1-44

Congressional Budget Office. 2012. Energy Security in the United States. Washington DC: CBO

Considine TJ. 2006. Is the Strategic Petroleum Reserve Our Ace in the Hole? The Energy Journal 27: 91112

Department of Homeland Security. 2012. ICS-CERT Monthly Monitor. Washington, DC

Deutch J, Schlesinger J. 2006. National Security Consequences of U.S. Oil Dependency Rep. Task Force Report No. 58, Council on Foreign Relations, Washington, DC

DiSavino S. 2013. Ten Years After NE Blackout, U.S. Power Grid Smarter, Sturdier. Reuters. http://www.reuters.com/article/2013/08/12/blackout-anniversary-idUSL2N0GD00V20130812

Federal Energy Regulatory Commission. 2013. Proposed/Potential North American LNG Import/Export Terminals. Washington, DC: FERC. http://ferc.gov/industries/gas/indus-act/lng/lng-proposedpotential.pdf

Fisher-Vanden K, Mansur ET, Wang Q. 2012. Costly Blackouts? Measuring Productivity and Environmental Effects of Electricity Shortages. Rep. WP No. 17741, NBER

Gillingham K, Newell RG, Palmer K. 2009. Energy Efficiency Economics and Policy. Annual Review of Resource Economics 1: 597-619 
Hamilton J. 2009. Causes and Consequences of the Oil Shock of 2007-2008. Brookings Papers on Economic Activity Spring 2009: 215-83

Hamilton JD. 2008. Oil and the Macroeconomy. In The New Palgrave Dictionary of Economics Online, ed. SN Durlauf, LE Blume. Basingstoke: Palgrave Macmillan

Hayashi M, Hughes L. 2013. The Policy Responses to the Fukushima Nuclear Accident and Their Effect on Japanese Energy Security. Energy Policy 59: 86-101

Holt M, Andrews A. 2012. Nuclear Power Plant Security and Vulnerabilities. RL34331. Washington, DC: Congressional Research Service

International Energy Agency. 2013. Energy Prices and Taxes, Third Quarter 2013. Paris: IEA

ISO New England. 2013. 2013 Regional Electricity Outlook, ISO-NE, Holyoke, MA

Joskow P, Tirole J. 2005. Merchant Transmission Investment. The Journal of Industrial Economics 53: 233-64

Kilian L. 2008. The Economic Effects of Energy Price Shocks. Journal of Economic Literature 46: 871-909

Kilian L. 2009. Not All Oil Price Shocks Are Alike: Disentangling Demand and Supply Shocks in the Crude Oil Market. American Economic Review 99: 1053-69

Kobayashi BH. 2005. An Economic Analysis of the Private and Social Costs of the Provision of Cybersecurity and Other Public Security Goods. Rep. 05-11, George Mason University School of Law

Leahy E, Devitt C, Lyons S, Tol RSJ. 2012. The Cost of Natural Gas Shortages in Ireland. Energy Policy 46: 153-69

Metcalf GE. 2006. Energy Conservation in the United States: Understanding its Role in Climate Policy. Rep. 138, MIT Joint Program on the Science and Policy of Global Change, Cambridge, MA

Metcalf GE. 2007. Federal Tax Policy Toward Energy. Tax Policy and the Economy 21: 145-84

Metcalf GE. 2008. An Empirical Analysis of Energy Intensity and Its Determinants at the State Level. The Energy Journal 29: 1-26

Metcalf GE. 2010a. Financing a National Transmission Grid: What Are the Issues? Rep. CEPE-5, The Manhattan Institute, New York

Metcalf GE. 2010b. Investment in Energy Infrastructure and the Tax Code. Tax Policy and the Economy 24: 1 - 33

Nakano J. 2013. Japan Gears Up its Quest for the "Best Energy Mix", Center for Strategic \& International Studies, Washington, DC 
National Research Council. 2009. Hidden Costs of Energy: Unpriced Consequences of Energy Production and Use. Washington, DC: National Academies Press

Nixon R. 1973. Address to the Nation About Policies To Deal With the Energy Shortages. In American Presidency Project, ed. J Wolley, G Peters. UCSDhttp://www.presidency.ucsb.edu/ws/index.php?pid=4034\&st=\&st1=\#axzz2iAXThp4e

Nordhaus WD. 2007. Who's Afraid of a Big Bad Oil Shock? Brookings Papers on Economic Activity 2007: 219-38

North American Reliability Council. 2012. 2012 Long-Term Reliability Assessment, NERC, Atlanta, GA

Nuclear Regulatory Commission. 2009. Protection of Digital Computer and Communications Systems and Networks. 10 CFR 73.54

Office of the President. 2003. Homeland Security Presidential Directive 7: Critical Infrastructure Identification, Prioritization, and Protection. HSPD-7. Washington, DC: Office of the Federal Register

Office of the President. 2013. Presidential Policy Directive - Critical Infrastructure Security and Resilience. PPD-21. Washington, DC: White House Office of the Press Secretary

Pan I. 2013. WTI Spread to Brent Crude Reaches Widest Level Since June. In Market Realist: Market Realist

Parfomak PW, Vann A. 2009. Liquefied Natural Gas (LNG) Import Terminals: Siting, Safety, and Regulation. RL32205: Congressional Research Service

Pigou AC. 1932. The Economics of Welfare. London: MacMillan and Co.

Schurr SH, Netschert BC. 1960. Energy in the American Economy, 1850-1975. Baltimore: Johns Hopkins Press

Smith JL. 2009. World Oil: Market or Mayhem? Journal of Economic Perspectives 23: 145-64

Sovacool BK. 2011. Evaluating Energy Security in the Asia Pacific: Towards a More Comprehensive Approach. Energy Policy 39: 7472-79

Sovacool BK. 2013. An International Assessment of Energy Security Performance. Ecological Economics 88: $148-58$

Sovacool BK, Mukherjee I. 2011. Conceptualizing and Measuring Energy Security: A Synthesized Approach. Energy 36: 5343-55

Toman MA. 1993. The Economics of Energy Security: Theory, Evidence, Policy. In Handbook of Natural Resource and Energy Economics, ed. AV Kneese, JL Sweeney, pp. 1167 - 218. Amsterdam: Elsevier 
U.S. Bureau of Economic Analysis. 2013. Fixed Asset Accounts. Washington, DC: BEA. http://bea.gov/iTable/index FA.cfm

U.S. Departments of Homeland Security and Energy. 2010. Energy Sector-Specific Plan. Washington, DC: Departments of Homeland Security and Energy

U.S. Energy Information Administration. 2013a. Cushing, OK WTI Spot Price FOB. Washington, DC: EIA. http://www.eia.gov/dnav/pet/hist/LeafHandler.ashx?n=PET\&s=RWTC\&f=D

U.S. Energy Information Administration. 2013b. Monthly Energy Review. Washington, DC: EIA

World Nuclear Association. 2013. Nuclear Power in Japan. http://www.world-nuclear.org/info/CountryProfiles/Countries-G-N/Japan/ 